\title{
DIFFERENTIATION AND TYPOLOGY OF THE MORAVIAN COUNTRYSIDE
}

Kateřina Stonawská ${ }^{1}$, Antonín Vaishar ${ }^{2}$

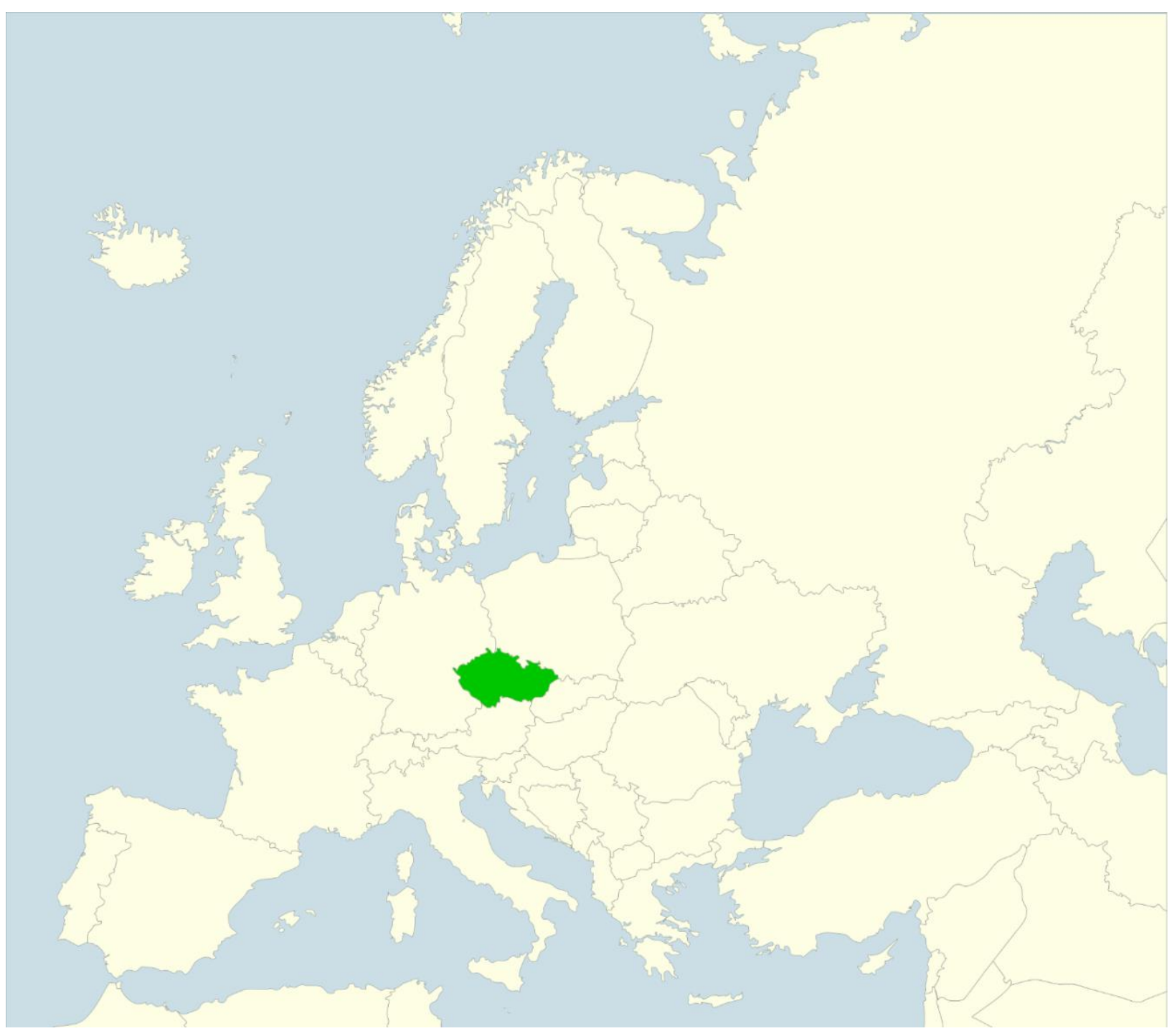

${ }^{1}$ Ing. Bc. Kateřina Stonawská, Ph.D., Ministry of Agriculture of the Czech Republic, Těšnov 17, 11000 Praha, Czechia; e-mail: katerina.stonawska@gmail.com

${ }^{2}$ Ass.Prof. RNDr. Antonín Vaishar, CSc., Department of Applied and Landscape Ecology, Faculty of AgriSciences, Mendel University in Brno, Zemědělská 1, 61300 Brno, Czechia; e-mail: antonin.vaishar@mendelu.cz 
Abstract: The authors argue that differentiation of various types of countryside is more important than to look for the definition of the rural against the urban. The paper is aimed at a typology of the Moravian countryside. Based on multifunctional (both hard and soft) data, Moravian micro-regions were divided into four categories - progressive, deficit and suburban countryside and predominantly urban micro-regions. Each of the categories has its own characteristics, threats, and needs. The authors stress that the approach of regional politics and both European and national subsidies have to take into account different categories of rural micro-regions. However, particular decisions have to be made in the intersection of the lowest regional level and the bottom-up approach expressed by community lead local development.

Key words: countryside, rural typology, Moravia

Souhrn: Autoři argumentují, že diferenciace různých typů venkova je důležitější než hledání definice venkova oproti městu. Článek je zaměřen na typologii moravského venkova. $\mathrm{Na}$ základě tvrdých i měkkých dat byly mikroregiony na Moravě rozděleny do čtyř kategorii: progresivní, deficitní a suburbanizovaný venkov a převážně městské mikroregiony. Každá z těchto kategorií má své vlastní charakteristiky, ohrožení a potřeby. Autoři zdůrazňují, že prístupy k regionální politice a podpora na evropské i celostátní úrovni by měla vzít tyto diference $v$ úvahu. Nicméně konkrétní opatření by měla vznikat na průsečíku nejnižší regionální úrovně a přístupu zdola nahoru, reprezentovaného komunitně řízeným místním rozvojem.

Klíčová slova: venkov, typologie venkova, Morava

\section{Introduction}

The delimitation of the countryside is a traditional geographical task. In the past, the dichotomy urban/rural was mostly used. However, is it really the most important problem of the rural research?

There is one practical necessity to define the countryside (rural communities, rural area) in the Czech Republic and in the European Union, namely in connection with subsidy programs for rural support and the effort to establish the countryside as a separate resort. For this purpose, the population density in various variants are used. As a matter of fact, there is no additional reason to define the countryside as the opposite of the city. On the contrary, permanent urbanization and migration processes are washing the limit between urban and rural. Many people live in the countryside but work in the city, regularly consuming both milieus. Urban elements penetrate to the countryside and vice versa. The urban rural dichotomy is changing for the core - periphery one (Grabski Kieron et al., 2016).

It is more or less clear that there are more "countrysides" even in such a small land as Moravia. Hypothetically, the suburbanized countryside is closer to the town (although it usually remains to be a countryside in terms of the land use, the size of the settlements etc.) whereas the periphery (with small town centers) seem to be a typical countryside. The space between the core and remote periphery (often fertile and relatively well accessible area) was a typical countryside in the past. However, its position is also changing in relation to the decrease of the importance of agriculture for the rural employment, rural incomes and rural way of life.

It seems that in urbanized countries, the typology of the countryside is much more important than a looking for the separation the village from the town. Different types of countryside have very unlikely characters and need different criteria of their evaluation, different instruments of their management and ultimately, different support from the center within the regional politics (see e.g. Baum et al., 2004). 
The paper is aimed at an attempt of a typology of Moravian countryside enabling such a differentiation. Moravian countryside has been chosen for the area under study because the centralized Bohemian and transitional Moravian settlement systems manifest different entities, which is more evident in the countryside than in cities. The differences between the Bohemian and the Moravian countryside appear also in Czech typologies (Perlín et al., 2010).

\section{Concept of rural, rural differentiation, rural typology}

To define the countryside or rural settlements respectively is not an easy task. The usual approach is based on a selection of the rural from the urban, the village from the city. There are several approaches to define rural areas both in international and national literature. ShambaughMiller (2007) states that only in the USA, there are 15 different rural definitions for the federal health program and 50 definitions for all government programs. These definitions have significant discrepancies in their spatial coverage. This is also confirmed by Bell (2007).

Woods (2011) explains the genesis of the term rural and its definitions. He distinguishes and analyzes in detail the political, media, academic and law understanding of the countryside. Warn (2010) points out the relativity of various definitions (who, where and with which aim defines the countryside). The concept of the countryside presents entirely different images for a farmer, lawyer or politician.

There are also some Czech approaches (Slepička, 1981; Keller, 1997; Čmejrek, 2008 or Kourilová et al., 2012). For the definition of rural areas, the density of the settlement or the absolute population, the urban or socio-professional structure or the architectural characteristics, the way of communication of the inhabitants, etc., are important (Perlín, 2010). However, the delimitation of the territory on the base of the core-periphery model also belongs to the frequently used geographical theories.

The "core-periphery" theory strictly separates space by the degree of concentration of economic activities. Friedmann (1967) sees the rural peripheral region as less innovative without greater development potential. Shucksmith, Thomson and Roberts (2005) complemented this theory with economic and political networks, since mere spatial proximity cannot be a sufficient condition for urban development with positive impacts on rural areas.

The diversification of rural areas based on innovation, sustainable development, quality of life, and intellectual values is also based on the "core-periphery" theory (Ward et al., 2005 or Holátová, Krninská, 2012). According to Leeuwes and van de Ban (2013), rural development will become more and more a question of the use of innovative systems. The theory of economic growth of rural regions and the impact of development policies on the development of rural areas is further explored by Cloke (2006) and Terluin (2001), who uses the theory to define rural areas within the EU. Galdeano-Gomez, Aznar-Sánchez and Peréz-Mesa (2010) have shown that rural development model cannot be generally found valid. Nevertheless, Bryden and Hart (2004) found in their research, that the rural regions can be distinguished by a combination of tangible and nonpalpable developmental elements.

National definitions of rurality within EU countries were summarized by Copus et al. (2008). The Czech Statistical Office defines a rural community and rural area based on statistical data (Fig. 1) and offers eight different definitions in its publication written by Tichá et al. (2008). They define the countryside with 30 selected indicators and differences between them. However, the precise definition of the countryside cannot be found according to Tichá at al. (2008): "Everyone perceives the country a bit differently, so the definition of rural space is to a large subjective extent. It is difficult to find the only acceptable criterion for defining the countryside." 


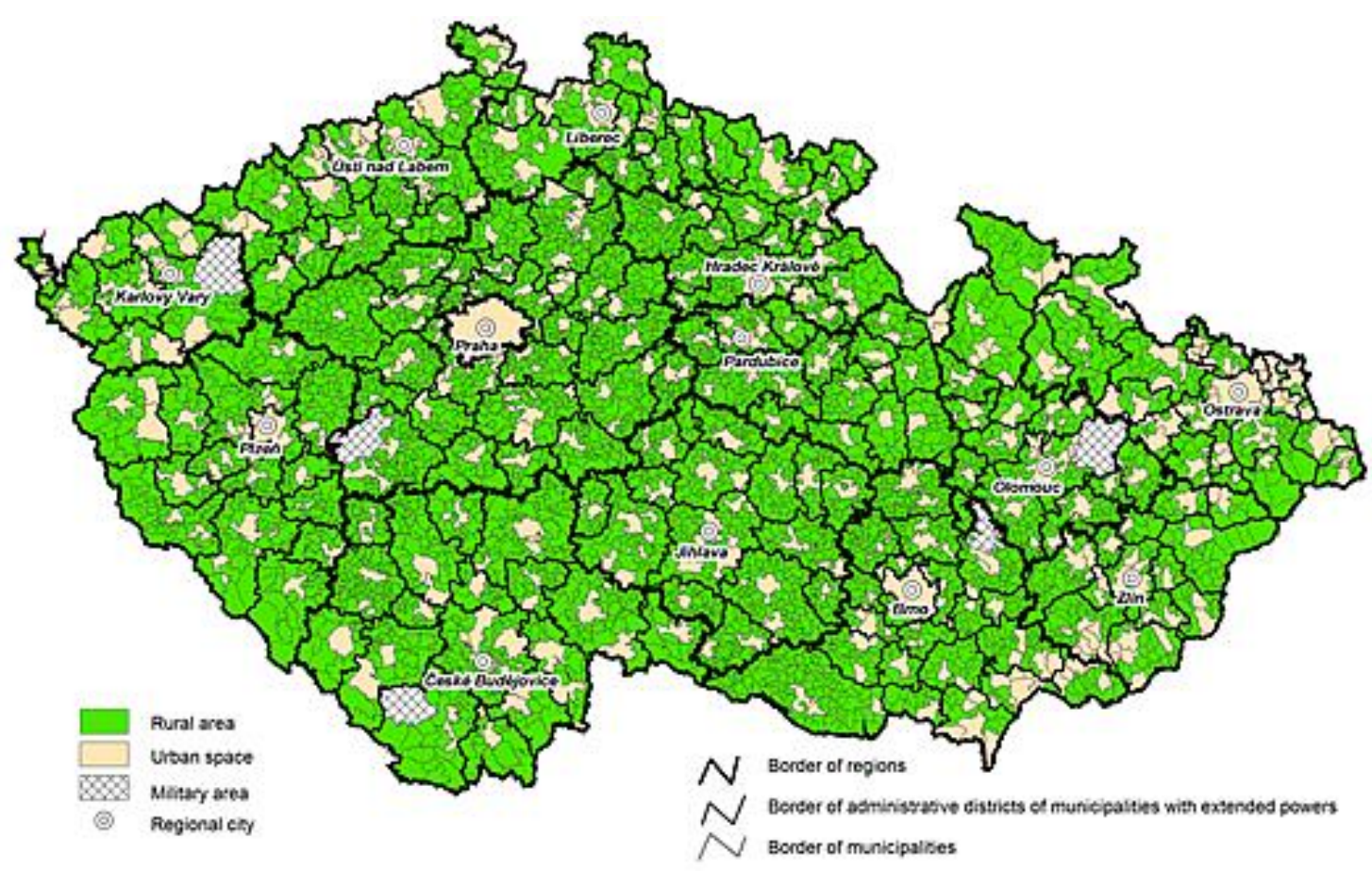

Fig 1. Delimitation of rural and urban space in the Czech Republic. Source: Czech Statistical Office (CZSO), 2016

The importance of soft factors in the rural definition is also known (e.g. Perlín, Kučera, Kučerová, 2010 or Ševčíková, 2010). They stressed that in addition to the geographical location and size of the village, human and social capital or cultural conditions can play a major role in the differentiation of rural areas too. Kocmánková-Menšíková (2011) are more inclined to the sociological conception of rural demarcation.

The Eurostat uses the population-based criterion combined with the population density set by the OECD, for the territorial delineation of rural areas. According to this definition (applied for NUTS 3 regions), the whole territory of the Czech Republic, without the capital city of Prague, was significantly or predominantly rural. Therefore it is clear, that national definitions must reflect more criteria and a more subtle territorial viewpoint.

There is a big difference between the countryside in Bohemia and in Moravia. The Moravian countryside is much more stable and more homogeneous, but with worse conditions for development (Perlín, 2009). The Czech settlement structure is heavily influenced by the natural conditions and historical development, it is highly fragmented and within the country, it is not uniform in character. This phenomenon is evident in Moravia even today. The larger municipalities in the area are situated in the lowlands of Moravia; on the other hand, the industrial northern part of Moravia has a high degree of urbanization - the seats are on average larger and more integrated here. The mountain part and some parts of the Moravian borderland are typical with small rural settlements.

Which factors impact on rural differentiation? These factors can be divided into general factors and individual factors. Among general factors, natural conditions (in terms of suitability for the agriculture, later for the tourism), accessibility from regional centers (distance and transport conditions), the path dependency (consequences of the historical development often related to special ethnic or religious conditions or changes of the geopolitical position like iron curtain) are taken into account. Of individual factors, let us mention the size (population number defining the size of the local market and pre-conditioning localization of services and jobs), human factor (human and social capital depending on local traditions, cooperation and ability of local governments), territorial factor (e.g., availability of plots for construction, specific features as e.g. risk of floods or specific configuration of main terrestrial communications).

In the European scale, van Eupen et al. (2012) dealt with rural typology. They stressed that such a typology should not be based on agricultural but on a multi-dimensional approach. The typology 
of the rural space in Czechia has been suggested by Perlín, Kučerová, and Kučera (2010). Hruška (2013) elaborated a typology of rural communes in Moravia-Silesian region. Similar delimitations and typologies were developed for some other European countries. Let us mention e.g., Bański and Stola (2002) for Poland or Prieto-Lara and Ocaña-Riola (2010) for Spain. Murdoch et al. (2003) defined the English countryside as preserved, contested, paternalistic and clientelist ones. Out of the European Union, Karáczonyi (2010) made a relative multi-disciplinary rural typology for Ukraine or Bogdanov et al. (2008) for Serbia.

\section{Material and methods}

Because the historical land Moravia as an administrative unit does not exist anymore, the delimitation of its territory compared to Bohemia and Silesia using the historical limit was the first step. Although the original borders were formed mostly by natural barriers (mountain ranges and forests), contemporary limits of administrative regions, districts, neither communes do not respect the historical division. It was necessary to make some approximation on the local level.

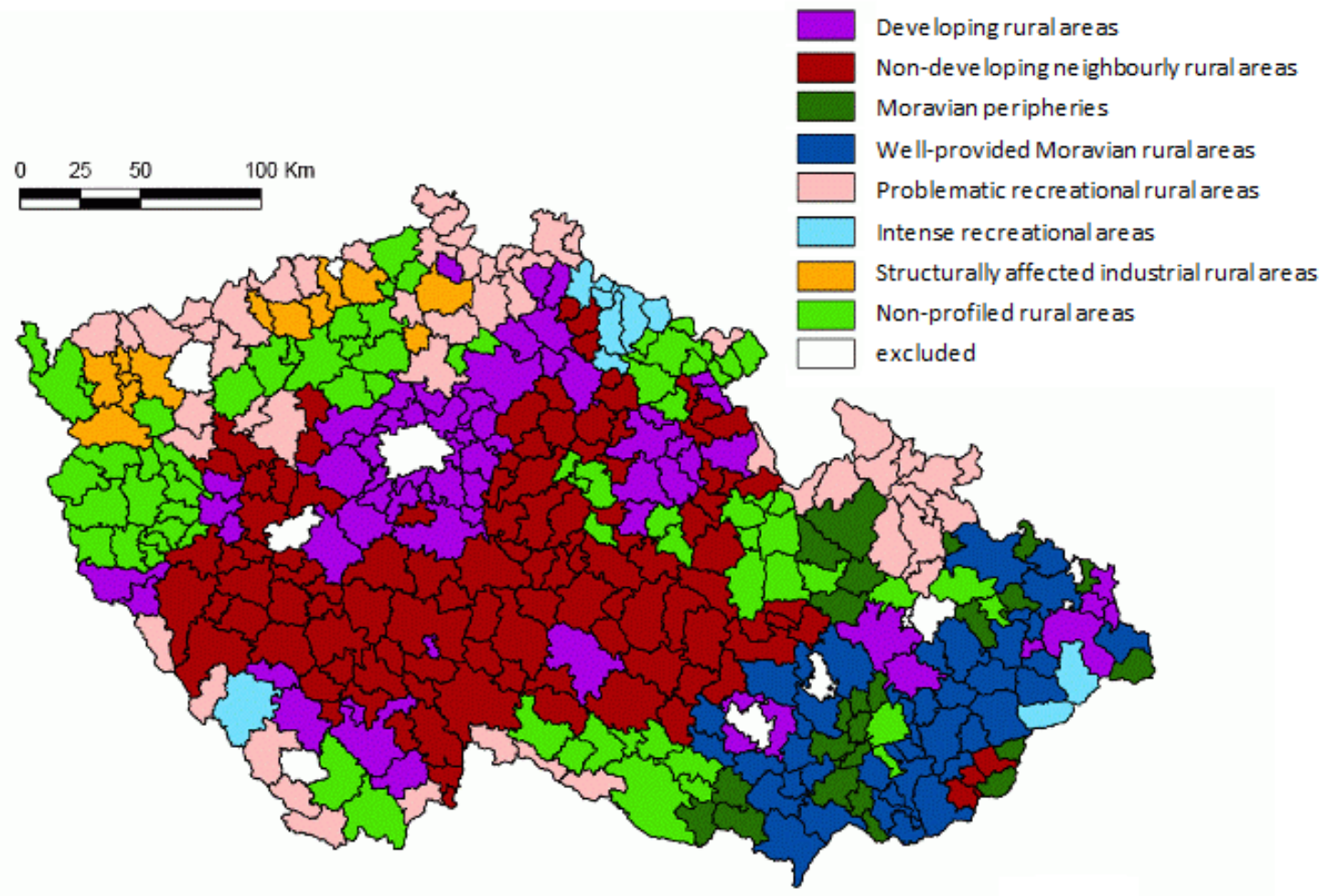

Fig 2. The typology of rural space in Czechia. Source: Perlín et al. (2010)

Opposite to some other investigations, micro-regions but not communes were chosen as territorial units for the investigation. They are represented by municipalities with extended competence ${ }^{3}$. Similarly, Perlín (2010, Fig. 2) used these territorial units for his typology. There are two reasons for this: firstly, some criteria do not have local but micro-regional character (e.g. job market), and secondly, the local approach (on the level of a commune or even a settlement) asks for better understanding of local peculiarities which is hardly possible from the centre. At the same time,

\footnotetext{
3 The last administrative reform of the Czech Republic has divided the territory of the country to 14 self-government regions (kraje) and 6,253 communes. The districts (okresy) remained as statistical units. Because the communes are too small in average, they are not able to fulfil their administrative duties. That is why municipalities with extended competencies were defined with the aim to ensure administrative functions for the communes in their hinterland on the professional level. Although such a solution is not very suitable from the administrative viewpoint, the new territorial units enable to analyse the area at the micro-regional level. They divide the territory unambiguously and completely and represent an intermediate step between too small communes and too large regions. Their size relates more or less to functional regions (in terms of commuting).
} 
the micro-regional approach includes some generalization whereas the local approaches create a seemingly chaotic mosaic.

The Moravian countryside is defined as an out-of-town area. That is why the delimitation of urban micro-regions was the next step. The following approaches to defining rural, based on institutional theory and seeking ways of possible development of rural areas, were taken into account: the size and geographical location of the administrative district of municipalities, agricultural production in the area, administrative districts of municipalities suitable for living and general environment and nature. The selected set of indicators is deliberately wide in order to best characterize rural areas. The set of selected indicators evaluates the population (demographic) characteristics, as well as the socio-economic situation, production or evaluation of housing stock. Proposed indicators are shown in the table 1 and they will be interpreted by primary data (census 2011) and secondary data (subjective survey).

Tab 1. Indicators to define and differ rural areas. Source: Stonawská, 2016

Indicators for defining rural areas

\begin{tabular}{|l|l|}
\hline $\begin{array}{l}\text { Statistical } \\
\text { [national } \\
\text { average] }\end{array}$ & $\begin{array}{l}\text { Density of population [134 persons } / \mathrm{km}^{2} \text { ], share of the agricultural land [53.4\%], } \\
\text { employment in the primary sector [2.5\%], share of permanently occupied } \\
\text { houses [83.4\%], share of population with completed tertiary education [12.5\%], } \\
\text { unemployment rate [3.8\%], total population growth [2.4\%o per year], share of } \\
\text { economically active people leaving for work outside the municipality [40.0\%], } \\
\text { migration balance [+1.9\%], age index [111.8] }\end{array}$ \\
\hline Subjective $^{4}$ & $\begin{array}{l}\text { Satisfaction with cultural life, sufficient cultural life, conditions for instigation, } \\
\text { quality of life }\end{array}$ \\
\hline
\end{tabular}

The abovementioned characteristics were expressed through the variables available for municipalities with extended competence. The actual typology of the countryside was made on the basis of the final results of the population and housing census 2011.

Its further categorization uses a multi-criteria approach, which takes into account all variables sorted into clusters. It is essential to individual variables also seen in terms of geography, not purely statistical, when grouping units into clusters. The creation of rural typology is based on a quantitative survey of hard statistical data subjected to cluster analysis performed at microregional level, municipalities with extended competence on the territory of Moravia.

The data were selected for subsequent analysis according to established indicators. This set of hard data (statistical data from census 2011, detailed to municipalities with extended competence) was subjected to a clustered analysis. Each indicator was determined by average value (or median) for the whole Czech Republic, which set the reference value of the individual variables. Subsequently, all variables were confronted with the reference value and the deviation of the given variable from the reference values were determined. The variables were sorted into groups according to the distance from the reference value, and the units were clustered according to the frequency of the same divergences.

Rural typology was based on the classification of the individual values of the indicators into clusters (groups), in which the units belonging to the same group were the most similar. The analysis defined four groups whose variables were the most similar. Quite different values of individual variables were obtained by the units with the highest value at the population density. These 19 municipalities with extended competence exceeded 150 inhabitants per $\mathrm{km}^{2}$ and therefore were evaluated as urban areas. For further investigation, they were preserved as

\footnotetext{
4 The values were gained from the questionnaire as a synthesis of answers on following questions: Is a sufficient cultural life in your commune? Are maintained and kept folk traditions there? Supports your commune the cultural and association life? Who is the main organizer of the cultural life there? Are favourable conditions for the entrepreneurship in your commune? Which strategy implements the unemployed people there? What is the most important condition for the quality of life in your commune? Is your commune attractive from the Quality of Life view?
} 
centres. Specifically, there are municipalities with extended competence such as Blansko, Brno, Frenštát pod Radhoštěm, Frýdek-Místek, Hodonín, Holešov, Kopřivnice, Kuřim, Nový Jičín, Olomouc, Ostrava, Otrokovice, Prostějov, Přerov, Šlapanice, Uherské Hradiště, Valašské Meziríičí, Zlín and Židlochovice. These administrative areas account for $29 \%$ of the total area of Moravia. They had a function of centres also according to the statistical and geographical evaluation - the high share of dwellings and the education index, the low share of out-of-town employment and higher employment in the tertiary sector.

The remaining units (municipalities with extended powers) were classified into three groups according to the greatest similarity in the surveyed variables. These three clusters form three categories of rural space in Moravia. Rural categories were identified according to the most significant differences in variables between groups and the linking of variables to the development of the territory as a progressive, deficit and suburban area.

The proposed typology was based on statistical data. However, it is important to reflect the influence of soft factors in determining the typology of rural areas. To penetrate deeper to the particular situation of individual categories of micro-regions, a combination of sociological methods and field research was used. Therefore, an inquiry was conducted in 10 chosen case areas selected in different categories of rural area types (tab. 2, marked in bold). The objective of this part of research consisted in a more detailed description of the typology of the Moravian countryside. The questionnaire surveyed subjective perceptions of model area residents. The PAPI method ${ }^{5}$ has been used to collect data, as this method has one of the highest reliability in terms of sample representativeness and maximum truthfulness of responses. Traditional local markets and feasts were used as a place where the respondents were contacted and addressed. Such events usually attract people from the selected locality and its surroundings. People are more willing to communicate with researchers.

In total, 256 respondents were addressed in the progressive countryside, 419 respondents in the deficient countryside and 174 respondents in the suburban countryside. Empirical research also aims to validate the typology.

\section{Differentiation and Typology of the Moravian Countryside}

The delimitation of rural micro-regions of individual types is in table 2 and in Fig. 3.

Tab 2. Catchment areas of the municipalities with extended competence in Moravia according to the proposed typology. Source: Stonawská, 2016

\begin{tabular}{|c|c|c|}
\hline $\begin{array}{l}\text { Category of rural } \\
\text { typology }\end{array}$ & Catchment areas of the municipalities with extended competence & total \\
\hline $\begin{array}{l}\text { Progressive } \\
\text { countryside }\end{array}$ & $\begin{array}{l}\text { Boskovice, Břeclav, Bučovice, Hustopeče, Ivančice, Jihlava, Litovel, Mikulov, } \\
\text { Moravský Krumlov, Pohořelice, Velké Meziř́ící, Znojmo }\end{array}$ & 12 \\
\hline Deficit countryside & $\begin{array}{l}\text { Bystřice nad Pernštejnem, Bystřice pod Hostýnem, Dačice, Hranice, Konice, } \\
\text { Kroměříž, Kyjov, Lipník nad Bečvou, Luhačovice, Mohelnice, Moravská } \\
\text { Třebová, Moravské Budějovice, Náměšst' nad Oslavou, Nové Město na Moravě, } \\
\text { Rožnov pod Radhoštěm, Rýmařov, Svitavy, Šternberk, Šumperk, Telč, Třebíč, } \\
\text { Uherský Brod, Uničov, Valašské Klobouky, Veselí nad Moravou, Vsetín, Zábřeh, } \\
\text { Žd'ár nad Sázavou }\end{array}$ & 28 \\
\hline $\begin{array}{l}\text { Suburban } \\
\text { countryside }\end{array}$ & Frýdlant nad Ostravicí, Rosice, Slavkov u Brna, Tišnov, Vizovice, Vyškov & 6 \\
\hline Urban areas & $\begin{array}{l}\text { Blansko, Brno, Frenštát pod Radhoštěm, Frýdek-Místek, Hodonín, Holešov, } \\
\text { Kopřivnice, Kuřim, Nový Jičín, Olomouc, Ostrava, Otrokovice, Prostějov, Přerov, } \\
\text { Šlapanice, Uherské Hradiště, Valašské Meziř́číi, Zlín, Židlochovice }\end{array}$ & 19 \\
\hline
\end{tabular}

\footnotetext{
${ }^{5}$ PAPI (pen and paper interviewing) method is a classic quantitative method of data collection in which the interviewer fills a standardized questionnaire with the respondent. Frequent questions are closed to which the respondent chooses answers from the help cards. Thanks to the minimum required equipment, the polling is very flexible, swift and can take place almost anywhere. The completed questionnaires are then rewritten into electronic form.
} 


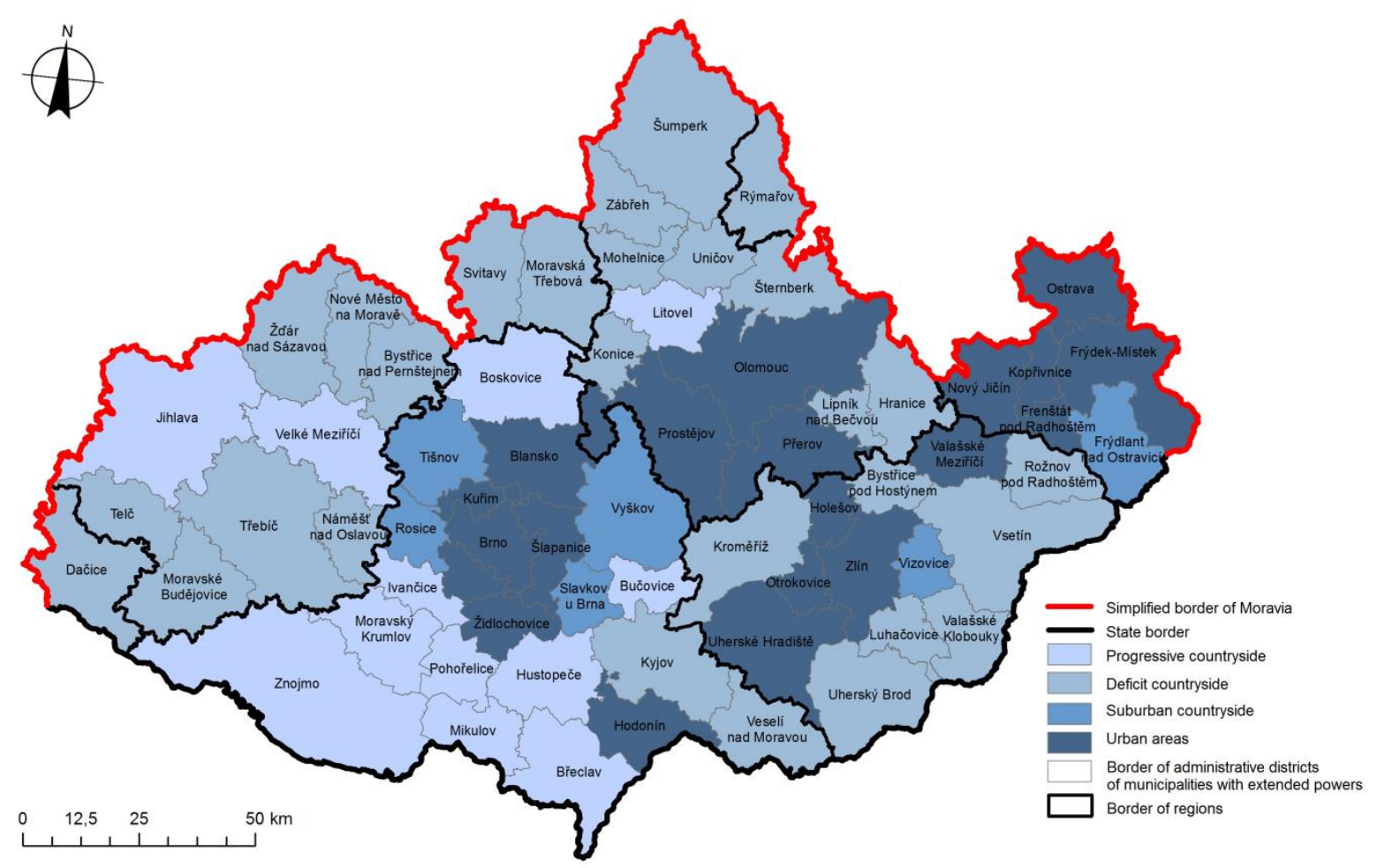

Fig 3. Typology of the Moravian Countryside. Source: the cartographical background: (CArcČR, ARCDATA, 2016, the content: Stonawská, 2017

It shows that the deficit countryside can be found near the Czech - Slovak borderline and close to the historical border between Bohemia and Moravia (which can be understood as a so called, Czech inner periphery; Musil and Müller, 2008). Dissected relief and thus worse accessibility of these rural areas are probably the main reason of the situation. At the same time, it is possible to state, that both borderlines are thousand-year old borderlines and thus territories at the end of the spheres influence the respective national or regional metropolis. This confirms the validity of the core - periphery theory for the differentiation of the countryside.

\subsection{Progressive countryside}

The progressive countryside consists of 12 administrative districts of municipalities with extended powers located in the south and west of Moravia and their area occupies 19\% of the total area of Moravia.

The primary indicator of the development of the territory is the positive value of the migration balance and the overall population growth, which assesses the cumulative change in the population due to birth, death, and migration. In the cluster analysis, 12 rural areas of municipalities with extended powers (Boskovice, Břeclav, Bučovice, Hustopeče, Ivančice, Jihlava, Litovel, Mikulov, Moravský Krumlov, Pohořelice, Velké Meziříčí and Znojmo) were significantly delineated and showed a positive variable of the total population increments. The variable migration balance of all these 12 units are positive. Among all the units evaluated in the territory of Moravia, this group showed favourable values for the variable age. The age index ${ }^{6}$ in the Czech Republic is 111.8 and the units merged into this group have a median of 106.7.

The variable share of agricultural land and employment in the primary sector indicate a strong link with agriculture - more than half of the territory (on average 64\%) of each unit is occupied by agricultural land and on average, $5 \%$ of the economically active inhabitants of the mentioned territory is working in agriculture, forestry and fishing. The variable share of commuting is higher than in all the units surveyed, but the difference is not significant.

\footnotetext{
${ }^{6}$ The age index is a quotient of young people (0-14 years) and seniors (65+ years).
} 
Negative relationships were noted for the aforementioned variables indicating prosperous areas with a variable unemployment rate.

Significantly positive values of the migratory variable and total population increment were indicated in six units. Catchment areas of Boskovice, Hustopeče, Jihlava, Pohořelice, Velké Meziřičí and Znojmo are, according to hard data, preferred for immigration and for setting up families, as confirmed by the low age indices in these units.

The results of the questionnaire survey show the satisfaction of the inhabitants with the cultural life of the area in all the model rural areas of the progressive countryside - on average, $85 \%$ of all respondents in the area believe that there are enough cultural activities in the village (even $96 \%$ of respondents are satisfied with cultural events in Znojmo). The respondents are satisfied with the favourable conditions for business development in their regions (on average $77 \%$ of respondents). More than three-quarters of respondents (84\% of the respondents from the region Velké Meziríćí, $77 \%$ of the respondents in Litovel and $76 \%$ of the respondents in the Znojmo region) consider their village to be attractive as regards the quality of life.

\subsection{Deficit countryside}

Deficit countryside consists of 28 administrative districts of municipalities with extended competence situated in the rural area of the northern and eastern part of Moravia and an outpost copying the course of the Bohemian-Moravian Highlands. With their size, these 28 areas occupy $43 \%$ of the territory of Moravia.

Predominantly, negative development characteristics are reported by the catchment areas of 28 municipalities with extended competence (Bystřice nad Pernštejnem, Bystřice pod Hostýnem, Dačice, Hranice, Konice, Kroměříž, Kyjov, Lipník nad Bečvou, Luhačovice, Mohelnice, Moravská Třebová, Moravské Budějovice, Náměšt' nad Oslavou, Nové Město na Moravě, Rožnov pod Radhoštěm, Rýmařov, Svitavy, Šternberk, Šumperk, Telč, Třebíč, Uherský Brod, Uničov, Valašské Klobouky, Veselí nad Moravou, Vsetín, Zábřeh and Žd'ár nad Sázavou). These areas have been allocated on the basis of the variables total population decline and population ageing. The unemployment rate was higher than the value set for the Czech Republic in all analyzed territories. Seven micro-regions from the study group were appointed in Government Resolution No. 560/2006 as regions with concentrated state support for the period 2007-2013 and 15 areas in this rural category are among economically problematic regions, which are supported by the state (Strategie regionálního rozvoje ČR 2014-2020).

The set of the micro-regions in the deficit countryside is not completely homogenous. There may be deviations, e.g., 6 micro-regions show a higher share of commuting, 9 micro-regions have higher values of people with university education.

In the analyzed areas, $5 \%$ of the economically active population is employed in the primary sector on average. This category of deficient rural micro-regions includes municipalities, where $2.18 \%$ of economically active inhabitants (Rožnov pod Radhoštěm) work in the primary sector in comparison to $8.13 \%$ of economically active inhabitants in Dačice. Due to deviations between variables, a larger representation of model territories from this set was chosen for the empirical part of the research.

In the case study areas, respondents are satisfied with the cultural life only in Třebič $(63 \%$ of respondents are satisfied, $19 \%$ of whom agree with enough cultural activities). More than half of the respondents are dissatisfied in the remaining micro-regions (69\% in Lipník nad Bečvou, 60\% in Šternberk).

Residents of the deficient rural area are relatively sceptical about the labour market and the business environment. On average, $63 \%$ of respondents do not think that their business conditions are favourable for business development. The worst situation for business is seen by the interviewees in Lipník nad Bečvou and Kroměřiž. In Lipník nad Bečvou, 72\% of respondents do not believe that their area offers opportunities for business, $71 \%$ of respondents feel the same in Kromerížz. The answers to this questionnaire are completely antagonistic, compared to the results obtained from progressive rural areas. 
The respondents were reluctant to see whether their village was attractive from the point of view of the quality of life, their answers were rather disappointing (58\% on average). The most negative answers were evaluated in the Kroměřiž region (31\% strongly disagree, $25 \%$ rather disagree). In contrast to that, $54 \%$ of respondents think that a high quality of life in their village can be found in the Třebič micro-region.

\subsection{Suburban countryside}

The suburban countryside consists of 6 administrative districts of municipalities with extended competence. These micro-regions are situated in the background of large cities (Brno, Ostrava, Zlín). The suburban countryside occupies $7 \%$ of the area of Moravia.

These 6 areas were the most variable in terms of consensus in cluster analysis. The variables were considerably consistent in the analysis with municipalities with extended competence Frýdlant nad Ostravicí, Rosice, Slavkov u Brna, Tišnov, Vizovice, and Vyškov. The statistical data at the micro-regions gained positive values in the variable positive migration balance and the overall natural increase. The variable age index has a median of 108.7, the variable unemployment rate shows low values. The share of university graduates in the population aged 15 and more was the highest in the total surveyed for all territories.

The areas of this cluster show low values in the variable employment in agriculture, forestry and fishing (average 2.6\%) compared to all the micro-regions concerned. Apart from Slavkov u Brna, none of the micro-regions in this group have more than $50 \%$ of the agricultural land on their territory. At the same time, the lowest share of commuters in Slavkov u Brna is from all the analyzed areas. Only in Rosice and Slavkov u Brna the variable population density is higher (143 and 145 inhabitants per $\mathrm{km}^{2}$ ).

In the villages on the Vyškov micro-region, $41 \%$ of respondents complained about the lack of cultural enjoyment. Vice versa in Rosice, $61 \%$ of respondents are satisfied with the possibilities of cultural activities.

Residents living in monitored territories perceived the business market and business development opportunities in their region positively. Almost three-quarters of respondents (74\%) are satisfied with the opportunities and conditions for business development in their municipality in Rosice, and $66 \%$ in Vyškov. In the micro-regions Vyškov and Rosice, the respondents were most satisfied with the quality of life in their village and $89 \%$ of respondents find it attractive in the area of Vyškov and $87 \%$ in Rosice.

\section{Conclusion}

The present Moravian countryside faces a number of different problems. Regions with a tradition of the agricultural production and located on major transport corridors are attractive for family formation. Municipalities support communal and cultural life, they care for public spaces and greenery. Large villages form a sufficient market for local producers and services. Progress is also evident in the small business. Vine-growing areas of the southern part of the land with most preserving folk traditions, manifest a special positive case with some tourist potential. However, in relation to the decrease of the importance of the primary sector in the employment and wealth creation, the imagination of these areas as rich regions changes step by step. Moreover, these fertile areas are endangered by the drought in relation to the climatic change. However, the positive development factor of these areas is not more connected with their fertility but rather with their accessibility, which can bring some problems of structural economic changes. The accessibility functions on both sides. Attractions of big and medium cities are accessible for the population of the progressive countryside but also the progressive countryside is accessible for urban dwellers who can transfer some activities to rural areas.

A different situation can be found in peripheral mostly mountain regions, which are not easily accessible by road or railway (measured by the time to overcome the distance). Preliminary small settlements do not create sufficient market to keep social infrastructure nor to complete the technical infrastructure. Villages depend on commuting to centres for jobs and services. Rural depopulation can occur in these rural areas, due in particular to the lack of attractive and well- 
paid jobs, bad business conditions and insufficient infrastructure. These deficiencies also entail deteriorating civic amenities. Population in these territories are ageing due to outmigration of young and educated people who desiderate richer, cultural and social life. The lack of funds is reflected not only in public buildings but also in family housing. On the other side, these territories with relatively well kept natural and historical heritage develop tourism and second living which often changes to the permanent one. Unfortunately, the touristic development is not able to bring high progress in Moravian conditions with a relatively short recreation season. On the other hand, these territories have always been poor and the life of the people is adapted to this fact.

Tab 3. An overview of individual types of the Moravian micro-regions.

\begin{tabular}{|l|c|c|c|}
\hline \multirow{2}{*}{ Indicator } & \multicolumn{3}{|c|}{ Type of the countryside } \\
\cline { 2 - 4 } & Progressive & Deficit & Suburban \\
\hline Population density per km ${ }^{2}$ & 95 & 87 & 111 \\
\hline Share of the agricultural land & $63.6 \%$ & $55.1 \%$ & $45.2 \%$ \\
\hline $\begin{array}{l}\text { Share of economically active population } \\
\text { employed in the primary sector }\end{array}$ & $5.3 \%$ & $5.0 \%$ & $2.6 \%$ \\
\hline $\begin{array}{l}\text { Share of people with the tertiary } \\
\text { education }\end{array}$ & $6.9 \%$ & $4.2 \%$ & $9.7 \%$ \\
\hline Share of permanently occupied houses & $84.8 \%$ & $81.2 \%$ & $83.5 \%$ \\
\hline $\begin{array}{l}\text { Share of economically active people } \\
\text { leaving for work outside the municipality }\end{array}$ & $45.2 \%$ & $47.8 \%$ & $46.5 \%$ \\
\hline Age index & 106.7 & 114.5 & 108.7 \\
\hline Share of unemployment & $10.6 \%$ & $12.2 \%$ & $9.2 \%$ \\
\hline Total migration balance & $+2.3 \%$ & $-1.5 \%$ & $+7.9 \%$ \\
\hline Satisfaction with cultural life & $85 \%$ & $45 \%$ & $51 \%$ \\
\hline $\begin{array}{l}\text { Satisfaction with the business } \\
\text { conditions }\end{array}$ & $77 \%$ & $37 \%$ & $70 \%$ \\
\hline $\begin{array}{l}\text { Perception of an Attractiveness in terms } \\
\text { of the quality of life }\end{array}$ & $79 \%$ & $42 \%$ & $88 \%$ \\
\hline
\end{tabular}

In the countryside, lying in the background of big cities, life is different, more dynamically developing. Extensive construction of family villas is connected with the expansion of municipalities, improvement of their civic amenities, reconstruction of transport hubs and roads. However, these facts threaten the very essence of this countryside as a rural area. Some mixture of urban and rural elements losing its original identity has been created.

It is more or less clear that there are at least three different countryside types within Moravia with various characteristics, and thus with different needs as concerns the support within the regional policy. As Copus and de Lima (2015) stress, the rural politics should be shifted from the agricultural politics to a general rural territorial cohesion. For this purpose, a new typology taking into account not only productive but multi-criterial factors should be implemented. Our paper should contribute to the discussion about such a rural typology. Of course, individual microregions and municipalities within individual types have plenty of individual characteristics and problems which cannot be solved from the centre. Regional politics of administrative regions should meet the bottom-up activities represented by the Community Lead Local Development

\footnotetext{
7 The last three indicators relate only to the micro-region, where the interviews were realized.
} 
within the LEADER initiative. More flexible funding structure is requested (Pollermann, Raue, and Schnaut, 2014).

The Moravian countryside is not an archaic designation for the territory that lies between the urbanized urban areas. While rural areas are confronted with a number of problems, it is necessary to bear in mind, that the countryside is the place where the relations of the population and their decisions shape the appearance of the village and the surrounding countryside.

At present, the countryside is considered as an attractive place to live, and urban dwellers increasingly prefer it. Moreover, the importance of the countryside is more often seen by government officials who are starting to strive to address infrastructure gaps, developer lobbying and social and economic problems. It is clear that efforts to develop rural areas will produce the first visible results after a long period of time. An active community approach in individual municipalities can help the quality of life and earlier community development and probably more effectively.

\section{Acknowledgement}

The paper was elaborated within the unspecific research of the Department of Applied and Landscape Ecology, AgriFaculty of the Mendel University in Brno.

\section{Academic References}

[1] Bański, J., Stola, W. (2002). Przemiany struktury przestrzennej i funkcionalnej obszarów wiejskich $w$ Polsce. Warszawa: Polskie towarzystwo geograficzne.

[2] Baum, S., Trapp, Ch. \& Weingarten, P. (2004). Typology of rural areas in the Central and Eastern European EU new member states [discussion paper]. Halle a. S.: Institute of Agricultural Development in Central and Eastern Europe.

[3] Bell, M. M. (2007). The two-ness of rural life and the ends of rural scholarship. Journal of Rural Studies. 23(4), pp. 402-415. DOI: 10.1016/j.jrurstud.2007.03.003.

[4] Bogdanov, N., Meredith, D. \& Efstratoglou, S. (2008). A typology of rural areas in Serbia. Economic Annals 177, 7-29. DOI: 10.2298/EKA08177007B.

[5] Bryden, J. \& Hart, K., eds. (2004). A new approach to rural development in Europe: Germany, Greece, Scotland and Sweden. Lewiston, NY: The Edwin Mellen Press.

[6] Čmejrek, J. (2008). Obce a regiony. Praha: Alfa.

[7] Cloke, P. (2006). Conceptualizing rurality. In: Cloke, P., Marsden, T. \& Mooney, P. H., eds., Handbook of Rural Studies (pp. 18-28). London: SAGE. DOI: 10.4135/9781848608016.n2.

[8] Copus, A., Psaltopoulos, D., Skuras, D., Terluin, I. \& Weingarten, P. (2008). Approaches to rural typology in the European Union. Luxembourg: European Communities.

[9] Copus, A. \& de Lima, P. (2015). Territorial cohesion in rural Europe. London and New York: Routledge.

[10] van Eupen, M., Metzger, M. J., Pérez-Soba, M., Verburg, P. H., van Doom, A., Bunce, R. G. H. (2012). A rural typology for strategic European policies. Land Use Policy 29(3), 473482. DOI: 10.1016/j.landusepol.2011.07.007.

[11] Friedman, J. (1967). A generalized theory of polarized development. Santiago de Chile: The Ford Foundation.

[12] Galdeano-Gómez, E., Aznar-Sánchez, J. A. A. \& Peréz-Mesa, J. C. (2010). The Complexity of Theories on Rural Development in Europe: An Analysis of the paradigmatic Case of Almería (South-East-Spain). Sociologia Ruralis. 51(1), 54-78. DOI: 10.1111/j.14679523.2010.00524.x. 
[13] Grabski Kieron, U., Mose, I., Reichert-Schick, A. \& Steinführer, A., eds. (2016). European rural peripheries revalued. Berlin: LIT Verlag.

[14] Holátová, D., Krninská, R. (2012). Lidské zdroje v rozvoji venkova. Praha: Alfa.

[15] Hruška, V. (2013). Diferenciace venkovského prostoru na př́kladu Moravskoslezského kraje [PhD theses]. Brno: Masaryk University.

[16] Karácsonyi, D. (2010). Ein Versuch der Typologie der ländlichen Räume in der Ukraine. Europa Regional 18(1), 34-50.

[17] Keller, J. (1997). Sociologie a ekologie. Praha: SLON, 1997.

[18] Kocmánková Menšíková, L. (2011). Sociální a kulturní kapitál lokálních aktérů v rozvoji venkova [PhD thesis]. Praha: Czech University of Life Sciences.

[19] Kouřilová, J., Květoň, V., Pělucha, M. \& Wokoun, R. (2012). Synergie vztahu město-venkov. Praha: Alfa.

[20] Leeuwis, C. \& van de Ban, A. W. (2003). Communication for rural innovation: rethinking agricultural extension. $3^{\text {rd }}$ ed. Ames, IA: lowa State Press.

[21] Murdoch, J., Lowe, P., Ward, N. \& Marsden, T. (2003). The differentiated countryside. London and New York. Routledge.

[22] Musil, J. \& Müller, J. (2008). Inner peripheries of the Czech Republic as a mechanism of social exclusion. Sociologický časopis 44(2), 321-348.

[23] Perlín, R., Kučerová, S. \& Kučera, Z. (2010). Typologie venkovského prostoru Česka. Geografie. 115(2), 161-187.

[24] Perlín, R. (2010). Theoretical approaches of methods to delimitate rural and urban areas. European Countryside 2(4), 182-200. DOI: 10.2478/v10091-010-0013-5.

[25] Pollermann, K., Raue, P. \& Schnaut, G. (2014). Opportunities for a participative approach in rural development: Findings from LAEDER in Mecklenburg-Vorpommern and the requirements for Community Lead Local Development. Landbauforschung 64(3/4), 127138. DOI: 10.3220/LBF_2014_127-138.

[26] Prieto-Lara, E. \& Ocaña-Riola, R. (2010). Upgrading rurality index for small areas in Spain. Social Indicators Research 95, 267-280. DOI: 10.1007/s11205-009-9459-0.

[27] Ševčíková, A. (2010). Vliv regionální politiky EU v Česku a Německu na rozvoj venkovských obcí (případová srovnávací studie) [PhD theses]. Praha: University of Life Sciences.

[28] Shucksmith, M., Thomson, K. J. \& Roberts, A. D. (2005). The CAP and the regions: the territorial impact of the common agricultural policy. Cambridge, MA: CABI.

[29] Slepička, A. (1981). Venkov a/nebo město: lidé / sídla / krajina. Praha: Svoboda.

[30] Stonawská, K. (2017). Moravský venkov ve světle sčítání lidu 2011 [unpublished PhD theses]. Brno: Mendel University in Brno.

[31] Terluin, I. J. (2001). Rural regions in the EU [PhD. Thesis]. Rijksuniversiteit Groningen.

[32] Ward, N., Atterton, J., Kim T.-Y., Lowe, P., Phillipson, J. \& Thompson, N. (2005). Universities, the Knowledge Economy and 'Neo-Endogenous Rural Development [Discussion Paper]. University of Newcastle upon Tyne.

[33] Warn, S. (2010). Rural development \& the countryside. Deddington: Philip Allan Updates.

[34] Woods, M. (2011). Rural. London and New York: Routledge. 
[35] ARCDATA (2016). Maps label of the territory of a municipality with extended competence containing data from Czech Statistical office. Praha: ARCDATA.

[36] Perlín, R. 2009. Vymezení venkovských obcí v Česku. Veřejná správa online. [retrieved 2013-09-22]. Accessible from: http://denik.obce.cz/clanek.asp?id=638406.

[37] Population and housing census 2011. Czech Statistical office Praha.

[38] Shambaugh-Miller, M. (2007). Development of a Rural Typology GIS for Policy Makers. $6^{\text {th }}$ Quadrennial Conference of British - Canadian - American Rural Geographers [retrieved 2015-11-28]. Accessible from:

http://cph.uiowa.edu/rupri/presentations/6th/\%20BCA/Symposhium/20Presentation.pdf.

[39] Strategie regionálního rozvoje ČR 2014-2020. Ministerstvo regionálního rozvoje ČR.

[40] Tichá, V. et al. Varianty vymezení venkova a jejich zobrazení ve statistických ukazatelích $v$ letech 2000 až 2006 [online]. Český statistický úřad, Praha, 2008 [retrieved. 2016-07-23]. Accessed from: https://www.czso.cz/ documents/10180/20536004/130808.pdf/5d2ad0ed8493-4237-a6d5-409614f287cf?version=1.0. 